ISSN 2078-6077.

Наукові зошити історичного факультету Львівського університету. 2020. Випуск 21. С. 128-143

Proceedings of History Faculty of Lviv University. 2020. Issue 21. P. 128-143

УДК: 94(477):001:82-051М. Возняк:140.8]”19”(093)

\title{
СВІТОГЛЯД ТА НАУКОВІ ІНТЕРЕСИ МИХАЙЛА ВОЗНЯКА: ФОРМУВАННЯ І СТАНОВЛЕННЯ
}

\author{
Леся КЛЕБАН \\ Львівський національний університет імені Івана Франка \\ 79000, м.Львів, вул. Університетська 1, кім. 337 \\ e-mail: lesja73@ukr.net
}

\begin{abstract}
На основі архівних джерел та історіографії акцентовано увагу на світогляді та наукових інтересах видатного літературознавця першої половини XX ст. Михайла Возняка. Основну увагу звернено на чинники, які були вирішальними у формуванні його світогляду, що в майбутньому зіграли принципову роль у літературознавчій діяльності вченого. Показано, як еволюціонували погляди й наукові інтереси франкознавця протягом трьох періодів його життєвого шляху: еміграційного, польського і радянського. Охарактеризовано також зв'язки академіка з відомими громадсько-політичними та науковим діячами, що мали безпосередній вплив на становлення його наукових інтересів.

Ключові слова: М. Возняк, світогляд, наукові інтереси, Академічна гімназія, Львівський університет, політичні переконання, еміграційний, польський, радянський періоди, К. Студинський, М. Драгоманов, М. Грушевський.
\end{abstract}

Досягнувши вершин у науковій сфері, Михайло Возняк залишається однією 3 найзагадковіших постатей української історії першої половини XX ст. не лише для пересічних громадян, але й для науковців. Його науковий шлях та життєвий досвід можна охарактеризувати словами Л. Міщенко: “багато сил $i$ часу віддав Михайло Возняк вихованню молодого покоління вчених. Він закликав свойх учнів дивитись на літературу як на живий організм, сприймати ї як душу народу. Студентам, аспірантам він передавав не лише знання, мудрість, але й тепло свого серия, батьківську любов. Він ніколи не повчав, але завжди був зразком порядності, чесності, приниииовості, працьовитості - найбільще важив тут власний приклад"1.

На особливу увагу заслуговує велика бібліографічна спадщина науковця. Тому $\epsilon$ важливим і актуальним визначити, які ж чинники впливали на його наукову творчість, як відбувалася еволюція його поглядів у різні періоди життя: еміграційний, польський та радянський.

Здобутки вченого та його внесок у розвиток українського літературознавства обговорювалися на наукових конференціях і в радянський період (9 жовтня 1981 року з нагоди 100-річчя від дня народження М. Возняка), i практично в наш час (20 березня 1990 року “Академік М. Возняк і розвиток

\footnotetext{
1 Леоніла Міщенко, “Син народу”, Академік М. Возняк і розвиток украӥнської національної культури. Наукові читання. Тези, (Львів, 20 березня 1990 р.): 7-8.

(C) Клебан Л., 2020 
ISSN 2078-6077. Наукові зошити історичного факультету Львівського університету. 2020. Випуск 21. Proceedings of History Faculty of Lviv University. 2020. Issue 21.

української національної культури”) у Львівському університеті. Виступаючи на одній із них, відомий львівський історик і культуролог Я. Ісаєвич наголосив, що "праці вченого (М. Возняка - Л. К.) з питань давньої літератури, мовознавства, фольклору, театру мали важливе значення ще тоді, коли закладались основи вивчення иих галузей науки. Дослідження про Котляревського, Сковороду, Коцюбинського, Шашкевича, Павлика, багаті новим фактичним матеріялом, озброювали читача новим розумінням розвитку демократичної української культури як єдиного процесу на Лівобережній та Правобережній Украӥні"'2.

Під час відкриття школи в рідному селі М. Возняка в 1983 р. Р. Іваничук та T. Салига проаналізували внесок вченого в літературознавчу ниву. Згодом з'явилася стаття “У селі академіка", яка побачила світ у “Літературній Україні”з.

Упродовж останніх років представники наукової школи академіка, його учні “пролили світло” та заповнили “білі плями” окремих аспектів наукової та громадсько-політичної діяльности М. Возняка. Зокрема до цього доклали зусиль його учні та співробітники М. Нечиталюк ${ }^{4}$, І. Денисюк ${ }^{5}$, М. Вальо ${ }^{6}$, В. Лесин ${ }^{7}$ та ин.

На сьогодні серед дослідників наукової діяльности Михайла Степановича слід відзначити М. Гнатюка ${ }^{8}$, Т. Салигу, Я. Мельник ${ }^{10}$, Л. Клебан ${ }^{11}$ та інших.

${ }^{2}$ Цит. за: В. Яковенко, “Ювілей академіка М. С. Возняка”, Радянське літературознавство, № 12, (1981): 90.

${ }^{3}$ В. Левицький, “У селі академіка”, Літературна Украӥна. 15 вересня 1983: 3.

${ }^{4}$ Михайло Нечиталюк, “Честь праці!!”: Академік Михайло Возняк у спогадах та публікаціях, (Львів, 2000): 424 с.; Михайло Нечиталюк, “Невтомний трудівник науки”, Жовтень, № 11, (1959): 149

${ }^{5}$ Іван Денисюк, “Академік з легенди”, Украӥнське літературознавство. Зб. наук. праць, Вип. 68. (2006): 402-424; Його ж. "Патріот і жрець науки”, Академік М. Возняк і розвиток української національної культури. Наукові читання. Тези., (Львів, 20 березня 1990 р.): 16-20; Його ж. “М. Возняк - фундатор українського франкознавства", Академік М. Возняк і розвиток украӥнської національної культури. Наукові читання. Тези., (Львів, 20 березня 1990р.):20-24.

${ }^{6}$ Марія Вальо, “Академік М. Возняк і книга”, Формування $і$ використання бібліотечних фондів (Київ, 1984): 98-106.; Ї̈̈ ж, "Неопублікована праця Академіка М.Возняка про рукописну спадщину Івана Франка", Записки Львівської наукової бібліотеки ім. В. Стефаника, Вип. 14, (2006): 260-282.

${ }^{7}$ В. Лесин, “Мій учитель”, Академік М. Возняк і розвиток украӥнськоїнаціональної культури. Наукові читання. Тези, (Львів, 20 березня 1990 р.): 10

${ }^{8}$ Михайло Гнатюк, “Давня українська література в інтерпретації М. Возняка”, Академік М. Возняк і розвиток української національної культури. Наукові читання. Тези, (Львів, 20 березня 1990 р.): 47-49;

9 Тарас Салига “...Живий мотор, що прилучив Галичину до всеукраїнського руху...” (У 200-літній ювілей Маркіяна Шашкевича: історико-літературознавчий аспект і сьогочасні проблеми...)”, Каменяр, листопад № 8, (2011): 1-2

10 Ярослава Мельник, "Студії поетичної творчості Івана Франка в науковій спадщині М. Возняка”, Академік М. Возняк і розвиток украӥнської національної культури. Наукові читання. Тези, (Львів, 20 березня 1990 р.): 35-37.

11 Леся Клебан, Наукова та громадсько-політична діяльність Михайла Возняка, (Львів, 2010): 190.; Її ж. “Громадсько-політична діяльність Михайла Возняка: переломний 1946 рік”, 
ISSN 2078-6077. Наукові зошити історичного факультету Львівського університету. 2020. Випуск 21. Proceedings of History Faculty of Lviv University. 2020. Issue 21.

При підготові дослідження використані й архівні матеріяли. Зокрема акцентована наша увага на документи фонду 29 (М. Возняк) з відділу рукописів Львівської національної наукової бібліотеки ім. В. Стефаника та партійного фонду Державного архіву Львівської області.

Mema cmammi - простежити еволюцію поглядів академіка на чільні проблеми українського державотворення, проаналізувати вплив взаємин Михайла Возняка $з$ провідними науковцями першої половини XX ст. та політичних чинників на наукові інтереси вченого.

Перші паростки національно-патріотичного світогляду М. Возняка сформувалися ще в ранньому дитинстві. Він виховувався в національносвідомій родині, про що дізнаємось із одного з листів брата Кирила до М. Возняка (1912р.), де відзначалося: “Будучи у Львові, задивлявся я ідеально на ту справу (піднесення національного духу - Л. К.), думав, щзо за один місяиь зроблю зі свого села непереможну українську твердиню, а тут нітрохи не сповнюються мої мрї" ${ }^{\prime 2}$. Родина дала майбутньому академікові дуже багато, як на той час, - можливість учитися, а відтак отримати краще життя. Виховуючись у багатодітній селянській сім’ї майбутній академік разом зі своїми братами, незважаючи на скрутне матеріяльне становище, здобув початкову освіту, бо “...батьки розуміли вагу освіти ..."13. Спочатку в рідному селі, а згодом - закінчив старші класи семирічної школи в м. Раві-Руській. Це дозволило М. Вознякові вступити до Академічної гімназії у Львові. Згадуючи про своє дитинство, він писав: " $Я$, пастух і помічник при сільському хазяйстві, не думав про подальшу освіту поза місиевою шестирічною школою в рідному селі. Та випадково з'явився в селі молодий інтелігент, що звернув увагу на заџікавлення сільського хлопчика й радив послати його до гімназії. А що до вступу до неї було потрібно знання початків німецької мови, яких не давала сільська школа, треба було змарнувати дальші два роки в Рава-Руській, щоб могти вступити до гімназї̈ з украӥнською мовою навчання у Львові. Ï̈ скінчив власними силами, заробляючи на життя корепетиціями й отримавщи в п'ятому класі стипендію 315 ринських річно"14.

Україна: культурна спадщина, національна свідомість, державність, № 17, (2008): 437-442; Ії ж. "Михайло Возняк в останні роки життя (1945-1954): критика та переслідування академіка", Наукові зошити історичного факультету Львівського національного університету імені Івана Франка, Вип. 17, (2016): 322-340. ІІї ж. “Михайло Возняк і Союз визволення України”, Україна: культурна спадщина, національна свідомість, державність, № 16, (2008): 307-315; Іїі ж. “Питання національної ідеї, державності та мови у працях Михайла Возняка, Вісник Львівського університету. Серія історична. Вип.50, (2014): 269-280

${ }^{12}$ Спр.523 (Возняк Кирило - брат, Листи до Возняка Михайла Степановича), Львівська національна наукова бібліотека ім. В.Стефаника НАН України (далі - ЛННБ ім. В.Стефаника), ф. 29 (Михайло Возняк), - 7 Арк.

13 Денисюк, “М. Возняк - фундатор українського франкознавства”, 20.

${ }^{14}$ Нечиталюк, “Невтомний трудівник науки”, 149 
Далі - навчання в Академічній гімназії у Львові, де фактично й почав формуватися світогляд майбутнього науковця, адже серед викладацького складу гімназії було багато відомих діячів: І. Кокорудза (директор), С. Федева (вчитель української мови), Ю. Левицький (вчитель історії), І. Боберський (вчитель німецької мова), М. Посацький (вчитель латинської і грецької мови), о. Монцібович (катехит) та ін. "Господарем класу” був проф. Лука Турчин (викладач німецької мови). Майбутній академік жив у бурсі Народного Дому. Однокласники М. Возняка походили з різних регіонів Західної України, проте “кляса була дуже зріднена, як одна родина", - згадував однокласник М. Возняка О. Охримович. У класі навчалися гімназисти, які в майбутньому стали відомими громадсько-політичними діячами та науковцями - це Василь Бобинський, Олександр Охримович, Іван Кней, Ілля Семенів, Іван Савчак, Федь Яцура, Степан Коцюба, Василь Свідрик, Лука Сологуб, Михайло Галань та ин. ${ }^{15}$

Політичні переконання відомого літературознавця формувались уже під час навчання на відділі української філології філософського факультету Львівського університету протягом 1904-1908 років. Тут він зіткнувся із зневагою поляків до українських студентів, що вкарбувалося у пам'яті засновника франкознавства. У пізнішому часі це стало однією з причин відмови М. Возняка присягнути на вірність Польській державі. Навчаючись в університеті, майбутній академік не міг стояти осторонь боротьби українців за вищий навчальний заклад, що розгорталася ще з кінця XIX ст. Тогочасна преса рясніла статтями, де обгрунтовувалася необхідність створити український вищий навчальний заклад, зокрема зазначалося, що “перед українською університетською молодіжжю у Львові, в повній своїй вазі давне завдання: боротьба за Львівський університет... ${ }^{16 "}$. Засновник франкознавства поділяв і підтримував протестну студентську хвилю, що наростала. Водночас було б помилково вважати, що він зосереджував значну увагу громадській чи політичній роботі. По-перше, бідність та скрутне матеріяльне становище змушували його думати про “сіру буденність", а саме про додаткові заробітки - допомога в навчанні иншим студентам. По-друге, уже в цьому віці яскраво проявлялася одна із найважливіших рис М. Возняка цілеспрямованість та скрупульозна робота над власним самовдосконаленням у науковій сфері, що забирало практично весь вільний час.

Першими науковцями, з якими починав співпрацювати М. Возняк ще бувши студентом - це два викладачі українознавства К. Студинський та О. Колесса. 3 О. Колессою стосунки в нього відразу не склалися, а після критичних випадів О. Колесси щодо роботи М. Возняка про граматику Лаврентія Зизанія ${ }^{17}$ геть ускладнилися. Майбутній франкознавець вважав, що

\footnotetext{
15 “Ювілейна книга Украӥнської академічної гімназї̈ у Львові”, (Філядельфія, 1978): 431.

16 Лесин, “Мій учитель”, 10

17 ЛННБ ім. В.Стефаника, ф. 29, спр.1, арк.4
} 
ISSN 2078-6077. Наукові зошити історичного факультету Львівського університету. 2020. Випуск 21. Proceedings of History Faculty of Lviv University. 2020. Issue 21.

О. Колесса "вище поставив польський мандат до австрійськой державної ради від почесного становища професора університету" i саме це заважало йому займатись наукою “...на заняття приходив рідко, викладав ї̈ (українська література - Л.К.) тільки в загальних рисах, ... для науки $і$ студентської молоді часу не мав..." ${ }^{18}$.

На відміну від О. Колесси, дружні стосунки М. Возняка склалися 3 К. Студинським. М. Возняк допомагав К. Студинському в науковій роботі й належав до його улюблених учнів ${ }^{19}$. Сам К. Студинський згадував: “разом зо мною сиділи при роботі мої щонайкращі студенти: Ярослав Гординський, Михайло Тершаковець, Михайло Возняк, Володимир Созанський, Юліян Чайковський і другі ${ }^{20 "}$ ".

До речі, I. Франко стежачи за розвитком наукового шляху цієї молодої генерації, зокрема і М. Возняка, також стверджував, що “на всіх... видно головно вплив проф. Студинського, бо проф. Колесса задля браку часу не вспів досі ані сам зазначити себе науковими прачями, крім тих, які належать до його перед професорських літ, ані виявити свій духовний вплив на своїх слухачів..."21.

Власне тоді і почали формуватися наукові інтереси молодого дослідника. Перші наукові роботи засновника франкознавства "справляли добре враження про автора, глибоко заангажованого в науку". Тому К. Студинський вважав, що "він [М. Возняк - Л. К.] заслуговує на звання дійсного член Товариства [НТШ - Л. К. ]22". 1911 року М. Возняка обрано дійсним членом філологічної секції НТШ за поданням саме К. Студинського. Проте ухвала секції не була затверджена Товариством, бо його члени, зокрема С. Томашівський та С. Рудницький вважали за необхідне підвищити вимоги до кандидатів на вступ у Товариство - вимагались науково виважені праці та ступінь доктора. Оскільки молодий дослідник не відповідав встановленим вимогам, його не прийняли до складу дійсних членів НТШ. 3 цих причин “Возняк був страшенно ображений... іна НТШ, зокрема, на Студинського...23". До речі, протягом усього наукового життя М.Возняк дуже болісно сприймав критику на свою адресу. 3 цього приводу його соратник I. Кревецький писав до фундатора-франкознавця: “дивно мені, щяо Ви берете собі так дуже до серия відносини, серед яких приходиться Вам працювати... Відносини ж сі, се ж невідлучний [атрибут - Л. К.]

18 ЛННБ ім. В.Стефаника, ф. 29, спр.1, арк. 3

${ }^{19}$ Нечиталюк, “Честь праці!": Академік М. Возняк у спогадах та публікаиіях, 372.

${ }^{20}$ Спр. 337 ( Кревецький І. Лист до Возняка Михайла Степановича), ЛННБ ім. В.Стефаника, ф. 29 , арк.2

${ }^{21}$ Уляна Єдлінська, Кирило Студинський. 1868-1941. Життєписно-біографічний нарис, (Львів, 2006): 112

${ }^{22}$ Сдлінська, Кирило Студинський. 1868-1941, 113

${ }^{23}$ Нечиталюк, “Честь прачі!": Академік М. Возняк у спогадах та публікачіях , 373 
ISSN 2078-6077. Наукові зошити історичного факультету Львівського університету. 2020. Випуск 21. Proceedings of History Faculty of Lviv University. 2020. Issue 21.

кожного украйнського письменника, щзо дійсно щось робив - пригадайте Драгоманова, Франка, Грушевського й инших ... ${ }^{24 ”}$.

За характером був "емоційний, вибуховий... як вітряк при буйному вimpi ... ${ }^{25 ", ~-~ т а к ~ з г а д у є ~ с в о г о ~ в ч и т е л я ~ и ̆ ~ н а с т а в н и к а, ~ М . ~ В о з н я к а, ~ у ч е н ь ~}$ I. Денисюк. "Був дуже великий нервус" - характеризує свого друга у спогадах В. Дорошенко.

Після закінчення університету Краєва Шкільна Рада рескриптом від 21 серпня 1908 року скерувала молодого науковця на викладацьку роботу до Академічної гімназії у Львові, де навчалися два його молодші брати ${ }^{26}$. Працюючи на педагогічній ниві, М. Возняк не полишав наукової діяльности. Основні свої праці публікував у літературному журналі “Неділя”. Пріоритетним напрямом студій того періоду для вченого стали постаті М. Шашкевича ${ }^{27}$ та Т. Шевченка, що пояснювалося ювілеями цих діячів (у 1911 р. - виповнювалося сто років від дня народження М. Шашкевича та п'ятдесять років від дня смерти Т. Шевченка). Водночас він був дописувачем друкованого органу “Просвіти” журналу “Письмо з "Просвіти” і вважав, що члени організації повинні виконати дві програми: мінімум - щоб не було ні одного неписьменного і максимум щоб не було ні одного неосвіченого, "тод $i$, - зазначав М. Возняк, - "Просвіта" просвітить i відродить нашу наиію $28 "$.

У 1914 р. вибухнула Перша світова війна. Молодий учений, як і більшість відомих діячів національно-демократичного табору, українських організацій та інституцій, покинув Галичину та переїхав до Відня. Тут він активно долучився до громадсько-політичної роботи, зокрема почав співпрацювати 3 СВУ, чільні діячі якого головним своїм політичним постулатом проголосили державну самостійність і соборність України. Разом з В. Дорошенком, М. Возняк редагував і коректував тексти у “Вістнику", а також був його активним дописувачем ${ }^{29}$. Власне тоді з-під його пера виходить низка працьроздумів про українську державність ${ }^{30}$. Серед найголовніших проблем утворення Української держави М. Возняк вважав національну ідею, виступав проти “федеративних мрій”. М. Возняк, не належав до жодної політичної сили, проте, на думку А.Жука, “тяжів до націонал-демократичного напрямуз"

24 ЛННБ ім. В. Стефаника, ф. 29, спр.337, арк. 2.

25 Денисюк, “Академік 3 легенди”, 405.

26 ЛННБ ім. В. Стефаника, ф. 29, спр.1, арк. 1.

27 Дет. див.: Леся Клебан, “Постать Маркіяна Шашкевича у працях Михайла Возняка”, Вісник Львівського торгово-економічного університету. Серія: Гуманітарні науки, Вип.14, (Львів, 2016): 35-39.

${ }^{28}$ В. Абашина, “Просвітницька діяльність М. Возняка", Академік М. Возняк і розвиток украӥнської національної культури. Наукові читання. Тези,. (Львів, 20 березня 1990 р.): 69.

${ }^{29}$ Дет. див.: Клебан, “Михайло Возняк і Союз визволення України”, 307-315.

30 Дет. див.: Клебан, “Питання національної ідеї, державності та мови у працях Михайла Возняка" 269-280.

${ }^{31}$ Спр. 294 (Жук А. Листи до Возняка Михайла Степановича), ЛННБ ім. В.Стефаника, ф. 29, арк. 1-3. 
ISSN 2078-6077. Наукові зошити історичного факультету Львівського університету. 2020. Випуск 21. Proceedings of History Faculty of Lviv University. 2020. Issue 21.

Вітав дослідник і проголошення самостійности України 22 січня 1918 року, підтримував підписання 9 лютого 1918 року Берестейського мирного договору. "Це дуже потішаючий факт, - відзначав М. Возняк, - бо тільки з'єднаними силами всіх партій і станів віднесе украйнська державність повну перемогу ${ }^{32}$ ". Ці дві події, на його думку, привели до того, що українські політичні партії у свої програми додали ідею незалежної Української держави. Водночас він зовсім серйозно дивувався, чому В. Винниченко, М. Грушевський, С. Петлюра і П. Скоропадський не можуть знайти між собою спільної мови, бо лише “... з'єднаність всіх українських державотворчих сил допоможе Українській державі вибрати собі таке необхідне для неї по-перше, утримання своєї державности, а по-друге, для осягнення справжньої незалежности ${ }^{33} "$. Найбільшою загрозою для утворення української державности вважав Російську імперію, “того самого павука, котрий не тільки не дає жити українському народові Росії, але и простяг свою ведмежу лапу й на той шмат украӥнської землі, де бодай пробоєм здобуває собі украӥнський народ умови самостійного національного життяз" українці повинні орієнтувався на Центральні держави ${ }^{35}$.

Повернувшись наприкінці війни, у 1918 р., до Львова, М. Возняк активно долучився до роботи в НТШ, брав участь в акціях товариства "Рідна Школа", був членом "Українського бібліографічного товариства" тощо, але "не займав ніяких офіціальних посад і займався виключно науковою роботоюз". Засновник франкознавства продовжував підтримувати тісні відносини 3 К. Студинським, який у 1924 р. клопотав перед ВУАН про присвоєння молодому науковцеві звання члена-кореспондента. У 1929 р. М. Возняка та ще кількох науковців Східної Галичини було обрано дійсними членами ВУАН ${ }^{37}$.

Особливість "раннього" М. Возняка - пошук предмету дослідження. Перші його роботи присвячувалися не Каменяреві, а відомим громадсько-політичним діячам, письменникам, поетам. У сферу наукових зацікавлень вченого потрапили Г. Сковорода, І. Борецький, І. Котляревський, П. Мирний, П. Грабовський, Леся Українка, М. Коцюбинський та ін. Серед серії розвідок, присвячених “третьорядним й четверторядним діячам українського письменства $X I X$ в. ${ }^{38}$ “, варто виокремити шевченківський доробок науковця. Дослідник

\footnotetext{
${ }^{32}$ Михайло Возняк, Українська державність, (Відень, 1918): 147-148.

${ }_{33}^{33}$ Возняк, Украӥнська державність, 147-148.

${ }^{34}$ Михайло Возняк, “За українське море та проливи”, Вістник, №. 17-18, (1916): 130-131.

${ }_{35}$ Олександр Рубльов, Західноукраїнська інтелігениія у загально-начіональних політичних та культурних процесах (1914-1939), (К, 2004): 195.

${ }^{36}$ Нечиталюк, “Честь праці! ”: Академік М. Возняк у спогадах та публікаціях, 181.

37 Дет. див.: Клебан, “Михайло Возняк в останні роки життя (1944-1954): критика та переслідування академіка”, 322-340.

${ }^{38}$ Михайло Возняк, “Автобіографічні знадібки до характеристики В. С. Александрова”, Украӥна,. Кн. 4, (Київ, 1928): 80.
} 
ISSN 2078-6077. Наукові зошити історичного факультету Львівського університету. 2020. Випуск 21. Proceedings of History Faculty of Lviv University. 2020. Issue 21.

присвятив Т. Шевченкові приблизно тридцять статтей, більшість із яких у радянський період “поверталися авторові “на доробку” або й відхилялися без жодних рецензійз"”. У своїх працях, зокрема ранніх, майбутній академік ілюстрував єдність українців по обох боках Дніпра, контакти провідних громадсько-політичних діячів, незламність сили духу в боротьбі за державницькі ідеали ${ }^{40}$. Національно-патріотичні погляди молодого літературознавця добре простежуються в його фундаментальній роботі “Історія української літератури”, яка побачила світ у 1924 році і присвячувалась “славній пам'яті невмирущих бориів за з'єдинену, вільну, самостійну й незалежну Україну ${ }^{41 " . ~ В л а с н е ~ ц я ~ п р а ц я ~ п р и н е с л а ~ м а и ̆ б у т н ь о м у ~ а к а д е м і к о в і ~ в и з н а н н я ~ у ~}$ науковому світі ${ }^{42}$. Вже в радянський час партійні органи критикували "Історію..." М.Возняка за "націоналістичні" погляди ${ }^{43}$.

Вдалі наукові спроби М. Вознякові додали впевнености, допомогли здобути авторитет та повагу серед низки відомих громадсько-політичних діячів як Галичини, так і за ії межами. М. Мороз справедливо відзначив, що: "наукові інтереси М. С. Возняка визначилися й сформувалися в першому десятилітті нашого віку (XX ст. - Л. К. $)^{44 ”}$. Наскрізною лінією мовознавчих наукових робіт академіка стала теза: “Без мови нема народности, рідна мова найкраще відбиває в собі думки й почуття иілої суспільности, всього народу... В мові, ї̈ історії ... відбилися прояви самостійного духовного життя будучого окремого народу4".

Дружні стосунки науковця склалися із В. Дорошенком - упорядником apхіву I. Франка, та І. Кревецьким - директором бібліотеки Наукового товариства ім. Шевченка (1909-1937 pp. із перервами). Упродовж наступних років їх співпраця в науковій сфері набула більш “усталеного характеру". М. Возняк активно підтримував почини директора бібліотеки НТШ, на якого покладалося завдання “реєструвати все, щьо було надруковане українською мовою, незалежно від змісту, начіональних, політичних, громадянських переконань авторів чи видавиів, правопису, шрифту (латинка, т.. “гражданський” чи “кириличний)".

Великий вплив на формування світогляду молодого науковця мали два відомі громадські діячі - М. Драгоманов та І. Франко. Першого згодом він

\footnotetext{
${ }^{39}$ Михайло Нечиталюк, “Штрих до Шевченкіани”, Жовтень, № 5, (1989): 118

${ }^{40}$ Михайло Возняк, Просвітницькі змагання галищьких украӥнців у XIX вічі (до 1895 р.), (Львів, 1912): 54.

${ }^{41}$ Возняк, Історія української літератури Т. 1., 1

${ }^{42}$ Спр.508 (Шимонович І. Листи до Возняка Михайла Степановича), ЛННБ ім. В.Стефаника, ф. 29 , арк. 3.

${ }^{43}$ Спр. 354. (Стенограмма V пленума обкома КП(б)У, Державний архів Львівської області (далі - ДАЛО), ф. 3 (Львівський обком Компартії України), оп. 2, арк. 113, 109.

${ }^{44}$ М. Мороз, “Фольклористична діяльність М.С. Возняка", Народна творчість та етнографія, № 6, (1981): 33.

${ }^{45}$ Возняк, Історія украӥнської літератури, Т.1, 15-16.
} 
ISSN 2078-6077. Наукові зошити історичного факультету Львівського університету. 2020. Випуск 21. Proceedings of History Faculty of Lviv University. 2020. Issue 21.

ідеалізував, називаючи провідним емігрантським діячем ${ }^{46}$, а другому присвятив сотні своїх наукових досліджень. У поле зору М. Возняка М. Драгоманов потрапив 3 огляду на свій внесок у розвиток державницької ідеї за кордоном. Адже "3/4 всього, що за останні 15 років писалось на чужих мовах про Україну, - писав академік, - або написано з приводу його публікачій $i$ за його ініціятивою. Коли ж він і менше писав, ніж треба було й він міг би був, багато в тому були винні Кияни, що не посилали потрібних йому книг, навіть своїх видань, і не давали йому фактичних інформачій 47 ". Також науковець захищав М. Драгоманова "від несправедливих нападів та обвинувачень Киян”, зазначаючи, що згідно з домовленостями, М. Драгоманов повинен був писати у "Громаді" “про европейські справи, а українськими обіияли зайнятися компетентніші від нього люди. Оскільки вони зі своїм завданням не справилися, М. Драгоманов мусив довчитись украӥнології на чужині, на що треба було багато часу та праиі ${ }^{48 "}$.

Що ж стосується I. Франка, то дослідження творчости Каменяра проходить через увесь життєвий та науковий шлях М. Возняка. Перші праці про I. Франка були написані ще за життя Каменяра, проте основні студії з'явилися в останні роки життя науковця або ж були опубліковані після його смерти. Власне для кращого дослідження творчости Івана Яковича, М. Возняк впроваджує до наукового обігу термін франкознавство, як окремий науковий напрям у гуманітарній сфері.

Протягом життя М. Вознякові пощастило співпрацювати з В. Щуратом, М. Грушевським та ин., які зіграли важливу роль у формуванні наукових та політичних уподобань молодого науковця.

Варто підкреслити, що для М. Возняка не існувало “авторитетів”, якщо мова йшла про встановлення правдивого історичного факту. Він активно дискутував i $з$ І. Франком, О. Колессою, В. Щуратом та иншими. Не винятком стали К. Студинський та М.Грушевський, які належали до його найближчих друзів. Обидва відомі громадські діячі та науковці мали відчутний вплив на наукові інтереси майбутнього академіка в міжвоєнний період. К. Студинський знав М. Возняка ще з університетських часів, а М. Грушевський почав співпрацювати $з$ фундатором франкознавства вже у ВУАН і став чи не найголовнішим меценатом його наукових праць у міжвоєнний період. До того ж зв'язок М. Возняка із Академією “створював матеріяльну незалежність від українських громадських та політичних організацій49". А що найголовніше - дозволяв академікові не займати жодних офіційних посад у

46 Михайло Возняк, 3 “Австороруських споминів”, Діло 1926; Його ж. “Із зносин М. Драгоманова із Галичиною”, Украӥна, Кн. 5 (19), (Київ, 1926):137-155; Його ж. “До історії місії М. Драгоманова", Україна, Кн. 32, (Київ, 1929): 52.

${ }^{47}$ М. Возняк, “До історії місії М. Драгоманова", 52.

${ }^{48}$ О. Куца, “М. Возняк про історичну місію М. Драгоманова”, 67.

49 О. Рубльов, Західноукраӥнська інтелігенція у загально-національних політичних та культурних прочесах, 180. 
Польській державі, яку “фанатично ненавидить” і вважав ії окупаційною на західноукраїнських землях.

Події, пов'язані зі встановленням радянської влади в західноукраїнських областях, змушують замислитися над питанням щирости і відданости західноукраїнської інтелігенції комуністичним ідеалам. У контексті цієї проблеми, варто підкреслити, що М. Возняк схвально відгукувався про нову форму української державности, якою була Радянська Україна. Зрештою “ладен був прийняти будь-який лад в Украӥні, аби його очолювали українці ${ }^{50}$ ". Тоді йому було повернуто наукове звання академіка, надано матеріяльну підтримку за роботу в Академії, він отримав можливість друкуватись в радянських виданнях, став депутатом Верховної Ради, очолив відділ літератури в АН УРСР у Львові, і за сумісництвом очолював катедру української літератури Львівського державного університету імені Івана Франка ${ }^{51}$. Проте, як слушно зауважував О. Луцький, “участь науковиів у прорадянських заходах не може слугувати беззаперечним доказом їх відданості тоталітарному режимові. У багатьох випадках науковиі, яких залучали до представницьких органів влади (К. Студинський, М. Возняк, I. Крип'якевич та ин.) прагнули передусім бути корисними співгромадянам, сподіваючись своїми діями пом'якшити політику режиму ${ }^{52}$ ".

Незважаючи на наукові й громадсько-політичні досягнення, саме радянський період для Михайла Степановича виявився одним із найважчих періодів, що пояснюється його непростими взаєминами із органами державнопартійної влади. М. Возняк не міг відкрито виступити проти радянської влади: адже тоді б він опинився на Соловках, де перебувало багато нашої інтелігенції. Тоді б він не досягнув тих наукових здобутків, які на сьогодні відомі. А тому він вирішив не виступати відкрито проти радянської влади і бути корисним науці. Хоча були випадки, коли науковець не каявся перед радянською владою за свої попередні праці, а тому в різкій формі відповів партійним керівникам: “... Чому ми (Терлецький, Кордуба і я) повинні каятися? Це були намі переконання, коли ми писали. Сприймайте нас такими, як ми є. Тепер ми стараємося инакше писати, але все ж пишемо, а ви не друкуйте нас, якщо ми погано пишемо... Я переконався, що серед комуністів немає розумних людей, а всі тільки рупори абстрактних доктрин, які виготовляються на кухні у Кремлі... Китайські стіни Кремля відгородили кремлівських кухарів від всього живого світу... ${ }^{53}$ ". Один із його учнів

\footnotetext{
${ }^{50}$ Нечиталюк, “Честь праиі! ”: Академік М. Возняк у спогадах та публікаиіях, 383.

51 Дет. див.: Клебан, “Громадсько-політична діяльність Михайла Возняка: переломний 1946 рік”, 437-442

52 Олександр Луцький, “Академічна наука в західних областях України в роки Другої світової війни”, Записки Львівської наукової бібліотеки ім. В. Стефаника НАН Украӥни, Вип. 13, (Львів, 2005): 411

${ }^{53}$ Інформація Львівського обкому КП(б)У для ЦК КП(б)У про відгуки наукових працівників Львова на критику концепцій М. Грушевського і його школи та на постанову президії АН УРСР
} 
ISSN 2078-6077. Наукові зошити історичного факультету Львівського університету. 2020. Випуск 21. Proceedings of History Faculty of Lviv University. 2020. Issue 21.

I.Денисюк слушно зауважив, що “академік ... не терпів жодних перекручень, найменшого відхилення від істини... ${ }^{54 "}$.

Проте позиція лавірування не захистила вченого від дискредитації. М. Возняка критикували за такі помилки: невідповідність методології марксизму-ленінізму, зв'язки із школою М. Грушевського, “небажання висвітлювати з погляду марксистсько-ленінської теорії літературні процеси, які відбувалися в Галичині у недалекому минулому 55 ". Подібні звинувачення стали можливими після остаточного становлення радянської влади на західноукраїнських землях та радянізації усіх сфер суспільнополітичного життя.

Відсутність порозуміння 3 партійними органами впливала на наукову діяльність. Тому, аби хоча б якось мати змогу займатись наукою, М. Возняк змушений був виконувати державні замовлення. Одними з таких були наукові студії академіка "До питання про походження Богдана Хмельницького"56 та "Письменницька діяльність Івана Борецького на Волині і у Львові" 57 , що приурочувалось 300-літтю “возз'єднання України з Росією”. У першій роботі автор простежив генеалогію відомого українського гетьмана, а у другій ствердив, що “діяльність Бореиького підготовляла трунт” для “возз'єднання”, що наступило за Богдана Хмельницького в Переяславі у 1654 р., оскільки “Іван Борецький взяв активну участь у боротьбі проти Берестейської релігійної унії 1596 року ${ }^{58 "}$. Після виходу праці М. Возняка "Іван Франко та передова російська культура" партійна критика дещо послабилася ${ }^{59}$.

Особливих зусиль в академіка, як керівника відділу, вимагала колективна монографія, що виконувала державне замовлення 3 дискредитації цілої когорти українських громадсько-політичних діячів - "Розгром українських буржуазних націоналістів - лютих ворогів українського народу". У результаті академік “самоусунувся від участі в ній, ... не дав ні рядка", а сама праця була незакінчена, що викликало “страшенний переполох серед партійного

про ліквідацію у Львові відділів науково-дослідних інститутів від 27 вересня 1946 року, Реабілітовані історією. Кн. 1. (Львівська область), (2009), 286.

${ }^{54}$ Денисюк, "Патріот і жрець науки", 18

${ }_{55}^{5}$ Спр. 80 (Стенограмма совещания интелигенции города Львова), ДАЛО, ф. 3, оп. 2, арк. 14; Спр. 354 (Стенограмма V пленума обкома КП(б)У), ДАЛО, ф.3, оп. 2, арк.109.

${ }^{56}$ Михайло Возняк, “До питання про походження Богдана Хмельницького”, 300 років возз'єднання Украӥни з Росією. Науковий збірник Львівського державного університету ім. I. Франка, (Львів, 1954): 94-101.

${ }^{57}$ Михайло Возняк, Письменницька діяльність Івана Борецького на Волині і у Львові, (Львів, 1954): 68.

${ }^{58}$ Возняк, Письменницька діяльність Івана Борецъкого на Волині і у Львові, 6.

${ }^{59}$ Спр.634 (Справки работников отдела о ходе подготовки научных кадров через аспирантуру в вузах и научно-исследовательских учреждениях, подборе, расстановке и воспитании профессорско-преподавательских кадров вузов и филиала АН УССР), ДАЛО, ф.3, оп. 2, арк. 7-8. 
ISSN 2078-6077. Наукові зошити історичного факультету Львівського університету. 2020. Випуск 21. Proceedings of History Faculty of Lviv University. 2020. Issue 21.

керівнищтва вищого рівня ${ }^{60}$ ". Критичні виступи радянських партчиновників проти М. Возняка остаточно викликали в академіка розчарування політикою радянської влади: “...як я не лавірував, але доведеться страждати. ... Шкода, щуо мало створив, але не шкода страждати. В иій крайні навіть нечесно буде, якщо не постраждати. Коли-небудь історія скаже, що був я не більшовик... ${ }^{61 "}$.

Поринувши з головою в науку, М. Возняк досягнув величезних результатів близько півтисячі наукових досліджень. Задля науки дослідникові довелося “відмовитись від багатьох радощів життя, крім насолоди від прачі. Ніколи не мав канікул, не виїжджав до будинків відпочинку, санаторіїв чи просто на гірське повітря. Намагався взагалі не виїжджати зі Львова, а як ие траплялося, то (жартували) ставались катаклізми світового масштабусвітові війни... “, - згадував один з його учнів І. Денисюк ${ }^{62}$. Життєвий девіз Михайла Возняка - "иілком пірнути у наукові студї, жити з них $i$ або загинути в боротьбі з труднощами, або довести до якихось результатів" "з.

Підсумовуючи, можна стверджувати, що світогляд науковця формувався під час навчання в Академічній гімназії у Львові, на філософському факультеті Львівського університету. Активну громадсько-політичну діяльність М. Возняк розпочав у роки Першої світової війни, коли почав працювати у “Вістнику" СВУ. У наукових працях М. Возняка еміграційного періоду домінувала політична тематика. Аналізуючи чільні проблеми українського державотворення, вчений констатував, що українська еліта не змогла сформувати єдиної національної ідеї, що стало однією з основних внутрішніх причин поразки в національно-визвольних змаганнях. Серед зовнішніх чинників, що стали на заваді утворенню української держави, він відзначив бажання сусідніх держав “будь-якими способами заволодіти Україною, визискувати природні багатства, мати користь з їі торговельних шляхів і культурних зв'язків".

Наукові зацікавлення вченого відрізняються своєю багатогранністю, та переломовою подією в науковому житті дослідника було знайомство із працями I. Франка, що в майбутньому стало пріоритетним напрямом наукової діяльности академіка. На наукові та політичні уподобання М. Возняка значний вплив справили відомі громадсько-політичні діячі: М. Грушевський, I. Франко, М. Драгоманов, В. Дорошенко, В. Щурат, К. Студинський.

Учений не прийняв Польської держави. Лояльно ставився до радянської влади, проте із засторогою сприймав іï ідеологічну складову. Водночас

\footnotetext{
${ }^{60}$ Дет. див.: Клебан, “Михайло Возняк в останні роки життя (1944-1954): критика та переслідування академіка", 322-340.

${ }^{61}$ Цит. за: Олександр Іщук, Наталія Ніколаєва, Реакиія львівської інтелігенції на розгром історичної школи Михайла Грушевського у 1946 рочі, (Київ, 2007): 13.

62 Денисюк, “Академік з легенди”, 406.

${ }^{63}$ Денисюк, “Академік з легенди”, 419.
} 
ISSN 2078-6077. Наукові зошити історичного факультету Львівського університету. 2020. Випуск 21. Proceedings of History Faculty of Lviv University. 2020. Issue 21.

М. Возняк залишився одним із небагатьох, хто не відмовився від вивчення проблем, які радянська історіографія “критично переосмислила”. Членство в низці українських організацій, виразні державницькі переконання в роки національно-визвольних змагань 1914-1923 років наклали відбиток на висвітлення його наукового та творчого доробку в радянський період. Згодом його праці розкритикує радянська історіографія в основному через надто довгі цитати, відсутність аналізу матеріялу та його критичне осмислення.

\title{
OUTLOOK AND SCIENTIFIC INTERESTS OF MYKHAYLO VOZNIAK: FORMATION AND DEVELOPMENT
}

\author{
Lesya KLEBAN \\ Ivan Franko National University of Lviv \\ room 337, Universitetska str, 1, Lviv, 79000, Ukraine \\ e-mail: lesja73@ukr.net
}

The article is based on archival sources and historiography to study the worldview and scientific interests of the famous literary critic of the first half of the twentieth century Mykhailo Voznyak. The main attention is focused on the factors that were decisive in shaping his outlook, which in the future played a fundamental role in the literary work of the scientist. The evolution of the views and scientific interests of the French scientist during the three periods of his life's journey is like this: emigration, Polish state and Soviet Union. The connections of the academician with famous socio-political and scientific figures who had a direct influence on the development of his scientific interests are described in this article.

The purpose of the article is to analyze the influence of the relations between Mykhailo Voznyak and the leading scientists of the first half of the twentieth century as well as political factors on the scientific interests and outlook of the scientist.

Political beliefs of a famous literary scholar were formed during the study of the department of Ukrainian philology at the Faculty of Philosophy of Lviv University during 1904-1908. Here he saw hard attitude of the Poles to Ukrainian students, which was embedded in the memory of the founder of French studies. In later times, this became one of the reasons for Vozniak's refusal to take an oath of allegiance to the Polish state.

The first scholars with whom the future scientist began to cooperate while still being a student were Kolesa and Studynsky, scholars in Ukrainian studies. With the latter, Voznyak had a friendly relationship. Actually, then the scientific interests of a young researcher began to ripen. The priority direction of his study of this period for the scientist became the figures of Shashkevych and Shevchenko It is explained by anniversaries (in 1911 - one hundred years since the birth of Shashkevych and fifty years since the death of Shevchenko). The peculiarity of "early" Wozniak is the search for the subject of study. His first works were devoted not to Kamenyar, but to wellknown public-political figures, writers, and poets such as Skovoroda, Boretsky, Kotlyarevsky, Grabovsky, Kotsyubinsky, Mirnyi, and Lesia Ukrainka.

During the First World War, a young scientist, like most well-known figures in the nationaldemocratic camp, left Galicia and moved to Vienna. Here he actively participated in publicpolitical work. Together with Doroshenko, he edited and carried out proofreading of texts. Actually, a series of works of reflections on Ukrainian statehood comes from his pen.

Two well-known public figures, Drahomanov and Franko, had a great influence on the formation of the outlook of a young scientist. He idealized them and devoted hundreds of his works to Franko, introducing "Franko-studies" into the scientific terminology as a separate scientific direction in literary criticism. 
ISSN 2078-6077. Наукові зошити історичного факультету Львівського університету. 2020. Випуск 21. Proceedings of History Faculty of Lviv University. 2020. Issue 21.

Famous scholars Studynsky and Hrushevsky belonged to the closest friends of Vozniak during the interwar years. He knew Studynsky from university times, and he began to cooperate with Hrushevsky already in Academy of Science. Actually, Hrushevsky became the most important sponsor of scientific works of famous literary critic during the Polish period. Voznyak's cooperation with the Academy made it possible to be materially independent from Ukrainian public and political organizations. The academician was not allowed to occupy any official positions in the Polish state, which he considered to be occupation regime in the West Ukrainian lands. Actually, during this period, one of his fundamental works, the three volume "History of Ukrainian Literature", came to light, which brought the future academician recognition in the scientific world and me became one of the reasons for persecution by his Soviet party organs.

The events associated with the establishment of Soviet power in the western regions of Ukraine make us think about the real sincerity and commitment of the Western Ukrainian intellectuals to the communist ideals. In the context of this problem, it should be emphasized that Voznyak considered Soviet Ukraine a new form of Ukrainian statehood. However, it was the Soviet period, which was one of the most difficult for him, due to his uneasy relations with the bodies of stateparty power. The scientist was criticized for such "mistakes" as the discrepancy between the methodology of Marxism-Leninism, and the links with the school of Hrushevsky. Voznyak could not openly oppose the Soviet authorities: because then he would be in Solovki, where there was a lot of our intelligentsia, and therefore he took the position of maneuvering to be useful to science.

Thus, it can be stated that the scholar's outlook was formed during his studies at the Academic Gymnasium in Lviv, the Faculty of Philosophy of Lviv University. Vozniak began his social and political activities during the First World War, when he began to work in the News. He did not accept the Polish state. He was loyal to the Soviet authorities, but without extreme acceptance of its ideological component. At the same time, Wozniak remained one of the few who did not refuse to study the problems that the Soviet historiography "critically rethought".

Membership in a number of Ukrainian organizations, expressive state beliefs during the years of the national liberation struggles of 1914-1923 marked the illumination of his scientific and creative work during the Soviet period. Subsequently, in his work he criticized by Soviet historiography mainly because of too long citations and the lack of analysis and critical reflection.

Key words: Voznyak, world outlook, academic interests, Academic Gymnasium, Lviv University, political persuasion, emigration, Polish, Soviet period, Studinsky, Drahomanov, Grushevsky.

\section{REFERENCE}

Autobiography him and personal sheet account of shots. 1939, 1940 Lviv National Science Library named after V. Stefanyk NAN Ukraine (further-LNNB V. Stefanyk), Fund.29 (M. Voznyak), Series 1, 14 Files, (in Ukrainian)

Abashyna, V. "Prosvitnycka diyalnist Mykhaila Vozniaka", Akademik M. Voznyak i rozvytok ukrainskoi natsionatnoi kułtury. Naukovi chytannya. Tezy, (Lviv, 20 March 1990 w.): 69. (in Ukrainian)

Denysyuk, Ivan. “Akademik z lehendy”, Ukrainske literatyroznawstwo, No. 68, (2006): 402424. (in Ukrainian)

Denysyuk, Ivan. "Patriot i zhrec nauky", Akademik M. Voznyak i rozvytok ukrainskoi natsionatnoi kuttury. Naukovi chytannya. Tezy, (Lviv, 20 March 1990 w.): 16-20. (in Ukrainian)

Denysyuk, Ivan. "M. Voznyak - fundator ukrainskoho frankoznavstva", Akademik M. Voznyak i rozvytok ukrainskoi natsionatnoi kułtury. Naukovi chytannya. Tezy, (Lviv, 20 March 1990 w.): 20-24. (in Ukrainian)

Ishchuk, Oleksander i Nikolayeva, Natalia. Reakciya lvivskoyi inteligenciyi na rozhrom istorychnoyi shkoly Mykhaila Hrushevskoho v 1946, (Kyiv, 2007): 34. (in Ukrainian) 
ISSN 2078-6077. Наукові зошити історичного факультету Львівського університету. 2020. Випуск 21. Proceedings of History Faculty of Lviv University. 2020. Issue 21.

Jakovenko, Natalia. “Juviley Akademika M. Voznyaka”, Radianśke literatyroznavstvo, No. 12,(1981): 90. (in Ukrainian)

Jedlinska, Ulyana. Kurulo Stydunsku. 1868-1941. Zhyttyepysno-biografichnyi narus, (Lviv: NTSH, 2006). (in Ukrainian)

Hnatyuk, Mikhailo. "Davnia ukrainska literatura v interpretaciyi Mykhaila Vozniaka", Akademik M. Voznyak i rozvytok ukrainskoi natsionatnoi kuttury. Naukovi chytannya. Tezy, (Lviv, 20 March 1990 w.): 47-49. (in Ukrainian)

Kleban, Lesia. Mykhailo Voznyak: naukova i hromadsko-politychna diyalnist (Lviv, 2010): 190. (in Ukrainian)

Kleban, Lesia. "Hromadsko-politychna diyalnist Mychaila Vozniaka: perelomnyi 1946 rik", Ukraina: kulturna spadshchyna, nacionalna svidomist, derzhavnist, No.17, (2008): 437442. (in Ukrainian)

Kleban, Lesia. "Mychailo Vozniak v ostanni roky zhyttia (1945-1954): krytyka ta peresliduvannia", Naukovi Zoshyty istorycznoho fakultetu Lvivskoho nacionalnoho universytetu imeni Ivana Franka, No. 17, (2016): 322-340. (in Ukrainian)

Kleban, Lesia. "Mychailo Vozniak I Soyuz vyzvolenia Ukrainy", Ukraina: kutturna spadshchyna, nacionatna svidomist, derzhavnist, No. 16, (2008): 307-315. (in Ukrainian)

Kleban, Lesia. "Pytannya nacionalnoi ideyi, derzhavnosti ta movy v praciakh Mykhaila Vozniaka", Visnyk Lvivskoho universytetu. Seria:istorychna, No. 50, (2014): 269-280. (in Ukrainian)

Kleban, Lesia.’Postat Markiana Shashkevycha v praciakh Mykhaila Vozniaka”, Visnyk Lvivskoho torhovo-ekonomichnoho universytetu. Seriya:Humanitarni nauky, No. 14, (Lviv, 2016): 35-39. (in Ukrainian)

Kuca, O. "Mykhailo Vozniak pro istorychnu misiyu M. Drahomanova”, Akademik M. Voznyak i rozvytok ukrainskoi natsionalnoyi kultury. Naukovi chytannya. Tezy, (Lviv, 20 bereznya 1990 w.): 66-68, (in Ukrainian)

Krevetsky, Ivan. Lysty do Vozniaka Mykhaila, LNNB V. Stefanyk, Fund 29, Series 337, 15 Files. (in Ukrainian)

Levyckyi, V. "U seli Akademika”, Literaturna Ukraina (1983) 15.09: 3. (in Ukrainian)

Lesyn, V. "Miy vchyteł”, Akademik M. Voznyak i rozvytok ukrainskoyi natsionatnoyi kuttury. Naukovi chytannya. Tezy, (Lviv, 20 March 1990 w.): 10. (in Ukrainian)

Lućkyj, Oleksandr . "Akademiczna nauka v zachidnych oblastiach Ukrainy v roky Drugoi svitovoj vijny”, Zapysky lvivskoi naukovoi biblioteky im. V.Stefanyka, No. 13, (Lviv, 2005): 411. (in Ukrainian)

Mełnyk, Yaroslava. "Stydiyi poetychnoyi tworchosti Ivana Franka v naukoviy spadshchyni Mykhaila Vozniaka", Akademik M. Voznyak i rozvytok ukrainskoi natsionatnoyi kułtury. Naukovi chytannya. Tezy, (Lviv, 20 March 1990 w.): 35-37. (in Ukrainian)

Mishchenko, Leonila. "Syn narodu”, Akademik M. Voznyak i rozvytok ukrainskoyi natsionalnoyi kultury. Naukovi chytannya. Tezy, (Lviv, 20 March 1990 w.): 7-8. (in Ukrainian)

Moroz, M. "Folklorystychna dialnist Mykhaila Vozniaka", Narodna tworchist ta etnohrafiya, No. 6, (1981): 33. (in Ukrainian)

Nechytalyuk, Mykhailo. "Czest praci!” Akademik Mykhailo Voznyak u spohadakh ta publikaciyakh, (Lviv, 2000): 424. (in Ukrainian)

Nechytalyuk, Mykhailo. "Nevtomnyi trudivnyk nauky", Zhovten, No. 11, (1959): 149. (in Ukrainian) 
ISSN 2078-6077. Наукові зошити історичного факультету Львівського університету. 2020. Випуск 21. Proceedings of History Faculty of Lviv University. 2020. Issue 21.

Nechytalyuk, Mykhailo. "Shtrykhy do Shevchenkiany”, Zhovten, No. 5. (1989): 118. (in Ukrainian)

Reabilitovani istoriyeyu. U 27 V. Za redakciyeyu Tronko P.: Lvivska oblast, Kn.1 (Lviv, 2009): 768 s. (in Ukrainian)

Rublyov, Oleksandr. Zakhidnoukrayinska intelihentsiya u zahalnonatsionalnykh politychnykh ta kyltyrnykh protsesakh (1914-1939), (Kyiv: Instytut istoryi Ukrainy NAN Ukrainy, 2004), 648. (in Ukrainian)

Salyha, Taras. “...Zhyvyi motor sho pryluchyv Halychynu do vseukrainskoho rukhu...” (The 200th anniversary of Markiyan Shashkevych: historical and literary aspect and modern problems ...), Kamenyar, No. 8 (2011): 1-2. (in Ukrainian)

Shymonovych, I. Lysty do Vozniaka Mykhaila, LNNB V. Stefanyk, Fund.29, Series 508, 7 Files. (in Ukrainian)

Stenohrama V plenyma obkoma KP(b)U, Derzhavnyi arkhiv Lvivskoyi oblasti (further-DALO), fund.3 (Lvivskyi obkom Kompartiyi Ukrainy), op.2, series 354, 211 Files. (in Ukrainian)

Stenohrama narady inteligenci mista Lvova, DALO, fund.3, op.2, series 80, 56 files. (in Ukrainian)

Spravky robitnykiv viddily pro khid pidhotovky naukovykh kadriv cherez aspiranturu u vuzakh i naukovo-doslidnykh ustanovakh, DALO, fund.3, op.2, series 634, 103 files, (in Ukrainian)

Valyo, Maria. "Akademik M. Voznyak i knyha", Formuvannya i vykorystannya bibliotechnykh fondiv (Kyiv, 1984): 98-106, (in Ukrainian)

Valyo, Maria. "Neopublikovana pracia Akademika M. Voznyaka pro rukopysnu spadshchynu Ivana Franka", Zapysky lvivskoyi naukovoyi biblioteky im. V.Stefanyka, No. 14, (2006): 260-282, (in Ukrainian)

Vozniak, Mykhailo. Ukrainska derzhavnist, (Viden, 1918): 152. (in Ukrainian)

Vozniak, Mykhailo. “Za Ukrainske more ta prolyvy”, Visnyk, No.17-18, (Viden, 1916): 130-131. (in Ukrainian)

Vozniak, Mykhailo. Prosvitnycki zmahannya halyckykh ukrayinciv u XIX w. (do 1850 r.), (Lviv,1912.): 54. (in Ukrainian)

Vozniak, Mykhailo. “Istoriya ukrainskoyi literatury”, V.1, (Lviv,1920): 344. (in Ukrainian)

Vozniak, Mykhailo. “Avstrorusynski spomyny”, Dilo, 1926 (in Ukrainian)

Vozniak, Mykhailo.’Iz znosyn M. Drahomanova iz Halychynoyu”, Ukraina, V.5 (19), (Kyiv, 1929): 137-155. (in Ukrainian)

Vozniak, Mykhailo. “Do istoriyi misiyi M. Drahomanova”, Ukraina, V.32, (Kyiv, 1929): 52. (in Ukrainian)

Vozniak, Mykhailo. "Do pytannya pro pokhodzhennya Bohdana Khmelnyckoho", 300 rokiv vozzyednannya Ukrainy z Rosiyeyu. Naukovyi zbirnyk, (Lviv,1954.): 94-101. (in Ukrainian)

Vozniak, Mykhailo. "Pysmennycka diyalnist Ivana Boreckogo na Volyni i u Lvovi”, (Lviv, 1954): 68. (in Ukrainian)

Vozniak, Kyrylo. - brat, Lysty do Vozniaka Mykhaila, LNNB V. Stefanyk, Fund.29, Series 523, 22 Files. (in Ukrainian)

Yuvileyna knyha Ukrainskoyi akademicnoyi Gimnaziyi u Lvovi, (Filadelfia, 1978): 431. (in Ukrainian)

Zhuk, Andriy. Lysty do Vozniaka Mykhaila, LNNB V. Stefanyk, Fund. 29, Series 294, 3 Files. (in Ukrainian) 
